\title{
Mastery of Science Concepts Improves Scientific Attitude in Elementary School Students
}

\section{Rajendra Cakra Artaga ${ }^{*}$}

${ }^{1}$ Prodi Pendidikan Guru Sekolah Dasar, Universitas Negeri Jakarta, Jakarta, Indonesia

\section{ARTICLE INFO}

Article history:

Received July 24, 2021

Revised July 30, 2021

Accepted September 30, 2021

Available online October 25, 2021

\section{Kata Kunci:}

Sikap Ilmiah Siswa, Penguasaan Konsep, IPA

Keywords:

Scientific Atittude Of Students, Mastery Of Natural Science Concepts.

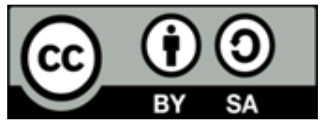

This is an open access article under the CC BY-SA license.

Copyright (@) 2021 by Author. Published by Universitas Pendidikan Ganesha.

\begin{abstract}
A B S T R A K
Banyak siswa yang memiliki kemampuan IPA yang rendah. Penelitian sebelumnya menyatakan bahwa masih banyak siswa yang mendapatkan nilai belajar IPA dibawah rata-rata. Penelitian ini bertujuan untuk menganalisis hubungan antara sikap ilmiah siswa dengan penguasaan konsep IPA kelas IV sekolah dasar. Jenis penelitian ini adalah penelitian kuantitatif dengan metode korelasional. Desain penelitian yang digunakan adalah merumuskan masalah-masalah dan menentukan tujuan penelitian. Subjek dalam penelitian ini adalah seluruh siswa berjumlah 58 responden yang diambil menggunakan teknik cluster random sampling. Metode yang digunakan dalam penelitian ini membahas dua variabel, variabel bebas yaitu sikap ilmiah siswa dan variabel terikat adalah penguasaan konsep IPA kelas IV sekolah dasar. Instrumen pengumpulan data penelitian ini menggunakan teknik pengukuran berupa 15 soal formatif pada variabel terikat dan lembar angket berjumlah 30 pada variabel bebas. Data dianalisis dengan statistik paramerik atau korelasi product moment. Hasil penelitian menunjukkan bahwa terdapat perbedaan hasil data sikap ilmiah siswa dengan penguasaan konsep IPA, data menunjukkan bahwa thitung sebesar 2,431 > ttabel sebesar 1,672 pada taraf signifikansi $\alpha=0,05$ dengan jumlah responden 58 siswa. Berdasarkan temuan tersebut, dapat disimpulkan bahwa terdapat hubungan yang positif antara sikap ilmiah siswa dengan penguasaan konsep IPA. Penguasaan konsep IPA dapat meningkatkan sikap ilmiah pada siswa.
\end{abstract}

\section{A B S T R A C T}

Many students have low IPA abilities. Previous research stated that there are still many students who get science learning scores below the average. This study analyzes the relationship between students' scientific attitude and mastery of science concepts in fourth-grade elementary school. This type of research is quantitative research with the correlational method. The research design used is to formulate problems and determine research objectives. The subjects in this study were all students totaling 58 respondents who were taken using the cluster random sampling technique. The method used in this study discusses two variables, the independent variable is students' scientific attitude, and the dependent variable is the mastery of science concepts for grade IV elementary school. The data collection instrument in this study used measurement techniques in 15 formative questions on the dependent variable and 30 questionnaire sheets on the independent variable. Data were analyzed by parametric statistics or product-moment correlation. The results showed differences in the results of students' scientific attitude data with mastery of science concepts. The data showed that tcount was $2,431>$ ttable was 1,672 at the significance level $=0.05$ with the number of respondents 58 students. Based on these findings, it can be concluded that there is a positive relationship between students' scientific attitudes and mastery of science concepts. Mastery of science concepts can improve students' scientific attitudes.

\section{INTRODUCTION}

Natural Sciences is a series of related concepts about objects and natural phenomena obtained from scientific investigations through experiments and observations using scientific methods (Lai et al., 2019; Maison et al., 2020; Subali et al., 2019). Natural Sciences has an essential role in human development regarding the application of concepts, tasks, natural considerations, virtue, hard work, interest, innovation, reliability, harmony, respect, and love for the homeland (Hanif, 2020; Rusli et al., 2020; Yunanto et al., 
2019). Natural Sciences are subjects at the elementary school level that explain nature developed by specialists through a series of scientific activities (Lai et al., 2019; Subali et al., 2019). Science has explicitly identified characteristics of real natural phenomena based on experiments and developed them based on hypotheses (Anif et al., 2020; Töman, 2017; Zabolotniaia et al., 2020). Science is seen as a way of thinking that results from the curiosity that makes humans always observe existing natural events. Science is related to science process skills, skills to study natural phenomena through specific ways to acquire knowledge and develop it (Abendroth \& Richter, 2021; Changwong et al., 2018; Töman, 2017). Science process skills are scientific skills aimed at finding a principle or theory, developing pre-existing theories, and carrying out the process of an invention (Lukman et al., 2019).

Science is a subject that has concepts that are interrelated and arranged systematically and theoretically. Learning Natural Sciences is the initial foundation for growing scientific knowledge, skills, and attitudes by systematically finding out about nature (Fartina et al., 2019; Hwang et al., 2012). Science is an essential subject for life with logical values and an efficiently organized collection of knowledge, hypotheses, and interrelated ideas from elementary to college (Fu et al., 2019; Seruni et al., 2020). The purpose of learning Natural Sciences in elementary schools can increase the mastery of practical science concepts and can be applied in everyday life (Darmaji et al., 2019; Sintema, 2020). There are three main components in science: attitudes, processes or methods, and scientific products (Lai et al., 2019; Subali et al., 2019). Scientific attitude or scientific attitude is defined as a situation that has an individual selfmeaning accompanied by certain feelings and descriptions in observing an object and doing something about the object being observed (Irwansyah et al., 2017; Maison et al., 2020).

The problem that occurs today is that many students have low science abilities. Previous research stated that many students still get science learning scores below the average (Dewi et al., 2013; Maison et al., 2020; Narayani, 2019). Many factors cause students to have difficulty learning science, one of which is learning media. Previous research has also stated that the lack of learning media impacts students' lack of understanding (Darmaji et al., 2019; Muhammad, 2018; Rosalina \& Suhardi, 2020). Learning media will help students with learning difficulties (Anindyajati \& Choiri, 2017; Maijarern et al., 2018; Saripudin et al., 2018). In addition, another factor is the learning model. The findings of previous research stated that there are still many teachers who use conventional learning models so that students feel bored in learning (Awe \& Benge, 2017; Dwi Lestari \& Putu Parmiti, 2020; Suryani et al., 2019). Inappropriate learning models will affect student learning outcomes (Arisantiani et al., 2017; Handayani et al., 2017; Widani et al., 2019). The teacher must consider this because it can affect students' abilities, especially scientific attitudes in students.

A scientific attitude is one's desire to develop new knowledge and respond to some issues according to scientific thinking (Rubini et al., 2018; Santiasih et al., 2013). Scientific attitudes are closely related to science concepts and science activities that can provide positive reinforcement and develop students' abilities to grow creative, independent, and responsible abilities (Rahayuningsih, 2020; Syahputra et al., 2017). Scientific attitudes in students can be formed through science teachers having a good picture and teaching science appropriately. Scientific attitudes can be used as a person's assessment of an object related to science to increase students' knowledge to answer, ask questions, discuss, and respect others (Latipah et al., 2020; Sakliressy et al., 2021; Suryawati \& Osman, 2018). There are eight parts of scientific attitude, namely; interest disposition, the mentality of need to get something new, essential reasoning attitude, disposition towards information or reality, open attitude, responsible mentality, persistence mentality, and self-control (Jatmiko et al., 2018; Maison et al., 2020). Scientific attitudes are interrelated with mastery of science concepts that can develop students' abilities and provide positive reinforcement.

Mastery of science concepts is an individual's ability to record and reanalyze information obtained through science subjects and can be used to solve problems (Fartina et al., 2019; Hwang et al., 2012). Mastery of the concept of science has an essential role for students to assist students in solving a problem that occurs in everyday life. Mastery of science concepts can help students to simplify, summarize, and organize the information received (Badu, 2013; Permana \& Nourmavita, 2017). In developing the idea of mastering science concepts in elementary schools, educators need to use exciting learning strategies or models to achieve significant learning (Fu et al., 2019; Seruni et al., 2020). Mastery of science concepts in elementary schools is essential for students to master because it will support student success in learning, develop an understanding of various natural phenomena and ideas, and apply them in everyday life (Darmaji et al., 2019). Learning Natural Sciences can guide students to protect the environment and be skilled in managing the environment. The learning interactions of basic education units must be interconnected, inspiring, fun, testing, and motivating students to be dynamic according to students' abilities, interests, and physical development (Lai et al., 2019; Maison et al., 2020; Sintema, 2020). The findings of previous research stated that the benefits for elementary school students studying Natural Sciences could be to foster a scientific attitude, instill belief in God Almighty, and gain the latest insight into 
the object being observed (Rusli et al., 2020; Subali et al., 2019). This study aims to analyze the relationship between students' scientific attitudes and mastery of science concepts in grade IV elementary school. It is hoped that IAP learning can improve students' scientific attitudes.

\section{METHOD}

This type of research is quantitative research with the type of correlation research. In this study, the sample used was elementary school students as many as 58 respondents. The data collection techniques used by the researchers in this study were formative questions and questionnaires-this study, using formative questions to obtain the desired data. There are 15 forms of dependent variable questions based on Bloom's taxonomy. The questionnaire has some questions and written statements submitted to respondents, namely to determine the relationship between students' scientific attitudes and mastery of science concepts in grade IV elementary school. The form of the questionnaire consists of 30 respondents with questions and statements of independent variables. In this study, the instrument used was in the form of a questionnaire (questionnaire). The questionnaire is the main instrument that needs to be used in this research. The reason for using a questionnaire is to obtain relevant information from this research. The preparation of the questionnaire uses a Likert scale with positive and negative gradations, which are vulnerable to a scale of 1 to 5 answers. Respondents were asked to choose one of the answers used to measure each indicator.

To find out whether or not the questionnaire instrument used in the research is feasible, the validity of the questionnaire must be tested first. In this case, the review is carried out by 2 experts, namely 2 lecturers. The considerations of the two experts are considered representative and the questions developed have met this validity requirement. Quantitative data will be analyzed with statistics between two variables. Descriptive statistics describe the independent variable (X) students' scientific attitudes and mastery of science concepts as the dependent variable (Y). While the parametric statistics used are Pearson productmoment correlation analysis techniques. The normality test conducted in this study aims to determine whether or not the distribution of the $\mathrm{X}$ and $\mathrm{Y}$ regression data to be analyzed is normal.

\section{RESULT AND DISCUSSION}

\section{Result}

This research was conducted at SD Negeri 01 Bendungan Hilir. After fulfilling the test requirements, data descriptions and hypothesis testing will be carried out to answer research questions. The data collected through this research are listed according to the data analysis needs listed in the research design to provide an overview of the data distribution. Furthermore, after the summary of the descriptive statistics, then look at the difference in frequency above using a histogram graph. The research results show that the highest frequency of students' scientific attitude scores is 105, and the lowest value is 71 . Then, the distribution of the frequency of mastery of science concepts is presented in a histogram graph.

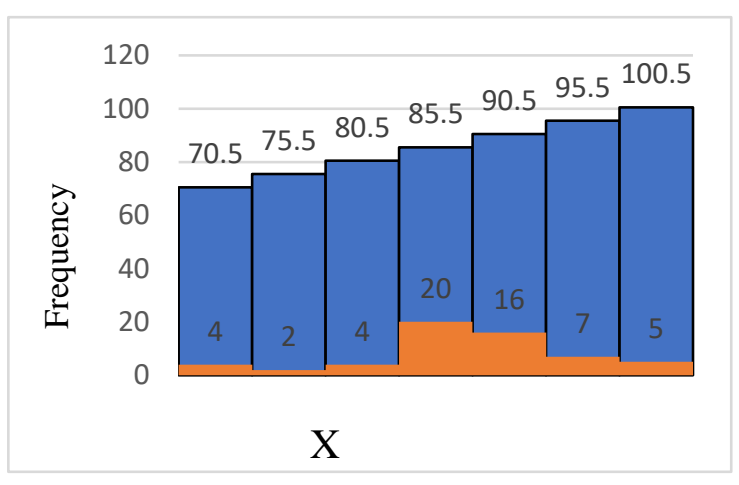

Figure 1. Histogram of Student Scientific Attitude

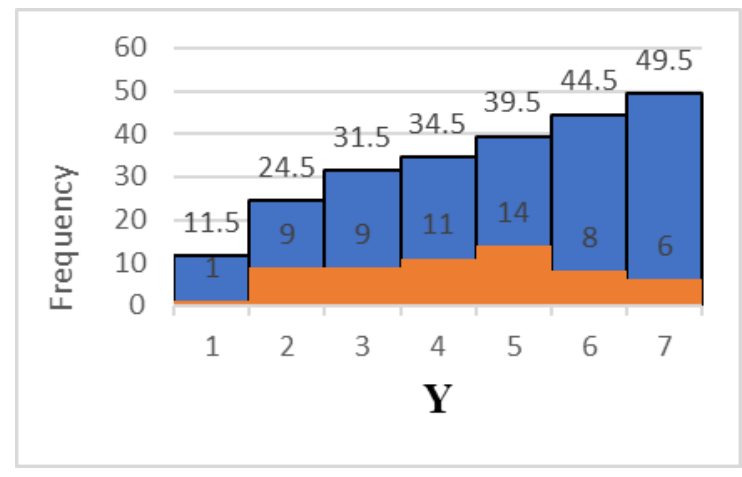

Figure 2. Histogram of Student Scientific Attitude

The research results on mastery of science concepts show the frequency of the highest value of 54 and the lowest value of 20 . Normality testing is carried out to determine whether the data is normally distributed or not. In this study, the Liliefors test was carried out with a significant $=0.05$. The analysis of the normality test of the estimated book error obtained Lcount $=0.087$ while the Liliefors test value was significant at $=0.05$ and obtained Table of 0.116 . So it can be concluded that the data is usually distributed. 
After the samples were normally distributed, followed by the linearity test, a linearity test was conducted to determine the relationship between the dependent and independent variables. A linearity test was carried out to confirm whether the linearity between the two identified variables was appropriate or not with the regression results and the linearity of the regression. After each variable has a linear pattern, then the correlation coefficient test is carried out. Calculation of the correlation coefficient in this study uses the product-moment correlation technique. Based on the correlation coefficient test between students' scientific attitude scores and mastery of science concepts, it was obtained tcount $=1.14$, while ttable at significance $=0.05$, then obtained ttable $=1.90$. Thus, it can be concluded that tcount $=1.14<1.90=$ ttable, which means that there is a significant relationship between variable $\mathrm{X}$ scientific attitude and variable $\mathrm{Y}$ mastery of science concepts.

\section{Discussion}

Based on the results of this study, there is a relationship between scientific attitude and mastery of science concepts. When viewed from the calculation of the correlation coefficient, the higher the scientific attitude of students, the higher the mastery of science concepts (Irwansyah et al., 2017; Novika Auliyana et al., 2018). On the other hand, the lower the students' scientific attitude, the lower the mastery of science concepts (Santiasih et al., 2013; Utomo et al., 2020). From the research results obtained from these calculations by the theory that Wyne Harlen has put forward, namely the high mastery of science concepts can make students have the ability to conduct experiments or experiments, have a curious attitude towards science learning (Lee \& Kim, 2018; Marisda \& Handayani, 2020). Based on statistical calculations, it can be concluded that there is a significant positive relationship between students' scientific attitudes and mastery of science concepts owned by fourth-grade elementary school students in the Bendungan Hilir sub-district, Central Jakarta.

A scientific attitude is a desire to develop new knowledge and provide responses by scientific thinking (Rahayuningsih, 2020; Syahputra et al., 2017). Scientific attitudes can provide positive reinforcement and develop students' abilities to foster creative, independent, and responsible abilities (Rubini et al., 2018; Santiasih et al., 2013). Scientific attitude can be used as a person's assessment in increasing students' knowledge to answer, ask questions, discuss, and the ability to respect others (Latipah et al., 2020; Sakliressy et al., 2021; Suryawati \& Osman, 2018). Scientific attitudes are interrelated with mastery of science concepts that can develop students' abilities and provide positive reinforcement in students. Mastery of the concept of science has an essential role for students to assist students in solving a problem that occurs in everyday life. Mastery of science concepts can help students simplify, summarize, and organize the information received (Bahari et al., 2018; Widiartini et al., 2019). In developing mastery of science concepts, educators need to use exciting learning models. Mastery of science concepts is essential for students to master because it will support student success in learning and developing an understanding of various natural phenomena to be applied in everyday life (Darmaji et al., 2019).

\section{CONCLUSION}

Based on the results of research and discussion, it can be concluded that the research results are: the relationship between students' scientific attitudes and mastery of science concepts is categorized as strong enough. Moreover, it is proven that there is a significant relationship between students' scientific attitudes and mastery of science concepts. It can be concluded that there is a significant positive relationship between students' scientific attitudes and mastery of science concepts owned by fourth-grade elementary school students. Mastery of science concepts can improve students' scientific attitudes.

\section{REFERENCES}

Abendroth, J., \& Richter, T. (2021). How to understand what you don't believe: Metacognitive training prevents belief-biases in multiple text comprehension. Learning and Instruction, 71(August 2020), 101394. https://doi.org/10.1016/j.learninstruc.2020.101394.

Anif, S., Sutopo, A., \& Prayitno, H. J. (2020). Lesson study validation: Model for social and natural sciences teacher development in the implementation of national curriculum in Muhammadiyah schools, Indonesia. Universal Journal of Educational Research, 8(1), 253-259. https://doi.org/10.13189/ujer.2020.080132.

Anindyajati, Y. R., \& Choiri, A. S. (2017). The effectiveness of using Wordwall Media to increase sciencebased vocabulary of students with hearing impairment. European Journal of Special Education Research, 2(2), 1-13. https://doi.org/10.5281/zenodo.236877.

Arisantiani, N. K., Putra, M., \& Ganing, N. N. (2017). Pengaruh Model Pembelajaran Childrens Learning In Science (Clis) Berbantuan Media Lingkungan Terhadap Kompetensi Pengetahuan IPA. Journal of 
Education Technology, 1(1). https://doi.org/10.23887/jet.v1i2.11774.

Awe, E. Y., \& Benge, K. (2017). Hubungan Antara Minat Dan Motivasi Belajar Dengan Hasil Belajar Ipa Pada Siswa Sd. Journal of Education Technology, 1(4), 231. https://doi.org/10.23887/jet.v1i4.12859.

Badu, S. Q. (2013). Implementasi Evaluasi Model Kirkpatrick Pada Perkuliahan Masalah Nilai Awal Dan Syarat Batas. Jurnal Penelitian Dan Evaluasi Pendidikan, 16, 102-129. https://doi.org/10.21831/pep.v16i0.1108.

Bahari, Darsana, \& Putra. (2018). Pengaruh Model Discovery Learning Berbantuan Media Lingkungan Alam Sekitar terhadap Hasil Belajar IPA. Jurnal Ilmiah Sekolah Dasar, 2(2). https://doi.org/10.23887/jisd.v2i2.15488.

Changwong, K., Sukkamart, A., \& Sisan, B. (2018). Critical thinking skill development: Analysis of a new learning management model for Thai high schools. Journal of International Studies, 11(2), 37-48. https://doi.org/10.14254/2071.

Darmaji, D., Kurniawan, D. A., Astalini, A., Kurniawan, W., Anwar, K., \& Lumbantoruan, A. (2019). Students' perceptions of electronic's module in physics practicum. Journal of Education and Learning (EduLearn), 13(2), 288-294. https://doi.org/10.11591/edulearn.v13i2.13005.

Dewi, Semara, \& Putra. (2013). Pengaruh Model Pembelajaran Siklus Belajar “(Learning Cycle)” 5E terhadap Hasil Belajar IPA Siswa Kelas V SDN 26 Pemecutan Denpasar Barat. Mimbar PGSD Undiksha, 2(1), 1-13. https://doi.org/10.23887/jjpgsd.v1i1.1207.

Dwi Lestari, H., \& Putu Parmiti, D. P. P. (2020). Pengembangan E-Modul IPA Bermuatan Tes Online Untuk Meningkatkan Hasil Belajar. Journal of Education Technology, 4(1), 73. https://doi.org/10.23887/jet.v4i1.24095.

Fartina, Hizbi, T., \& Syahidi, K. (2019). Development of Interactive Physics Learning Media Macromedia Flash 8 Based on Straight Motion Material. Journal of Physics: Conference Series, 1539(1). https://doi.org/10.1088/1742-6596/1539/1/012023.

Fu, Q.-K., Lin, C.-J., Hwang, G.-J., \& Zhang, L. (2019). Impacts of a mind mapping-based contextual gaming approach on EFL students' writing performance, learning perceptions and generative uses in an English course. Computers \& Education, 137. https: //doi.org/10.1016/j.compedu.2019.04.005.

Handayani, N. M. D., Ganing, N. N., \& Suniasih, N. W. (2017). Model Pembelajaran Picture and Picture Berbantuan Media Audio-Visual Terhadap Pengetahuan IPA. Journal of Education Technology, 1(3), 176. https://doi.org/10.23887/jet.v1i3.12502.

Hanif, M. (2020). The development and effectiveness of motion graphic animation videos to improve primary school students' sciences learning outcomes. International Journal of Instruction, 13(4), 247-266. https://doi.org/10.29333/iji.2020.13416a.

Hwang, G. J., Wu, P. H., \& Chen, C. C. (2012). An online game approach for improving students' learning performance in web-based problem-solving activities. Computers and Education, 59(4), 12461256. https://doi.org/10.1016/j.compedu.2012.05.009.

Irwansyah, F. S., Lubab, I., Farida, I., \& Ramdhani, M. A. (2017). Designing Interactive Electronic Module in Chemistry Lessons. Journal of Physics: Conference Series, 895(1). https://doi.org/10.1088/17426596/895/1/012009.

Jatmiko, A., Kartina, Y., Irwandani, I., Fakhri, J., Pricilia, A., \& Rahayu, T. (2018). Reading Concept Map-Think Pair Share (Remap-TPS) Learning Model on Cognitive Ability and Scientific Attitude. Jurnal Keguruan Dan Ilmu Tarbiyah, 3(2). https://doi.org/10.24042/tadris.v3i2.3184.

Lai, A., A. F., C., \& Lee, G. Y. (2019). An augmented reality-based learning approach to enhancing students' science reading performances from the perspective of the cognitive load theory. British Journal of Educational Technology, 50(1), 232-247. https://doi.org/10.1111/bjet.12716.

Latipah, E., Kistoro, H. C. A., \& Khairunnisa, I. (2020). Scientific Attitudes in Islamic Education Learning: Relationship and the Role of Self-Efficacy and Social Support. Edukasia: Jurnal Penelitian Pendidikan Islam. https://doi.org/10.21043/edukasia.v15i1.7364.

Lee, S., \& Kim, S. H. (2018). Scientific Knowledge and Attitudes Toward Science in South Korea: Does Knowledge Lead to Favorable Attitudes? Science Communication, 40(2), 147-172. https://doi.org/10.1177/1075547017753189.

Lukman, A., Hayati, D. K., \& Hakim, N. (2019). Pengembangan Video Animasi Berbasis Kearifan Lokal pada Pembelajaran IPA Kelas V di Sekolah Dasar. Elementary: Jurnal Ilmiah Pendidikan Dasar, 5(2), 153. https://doi.org/10.32332/elementary.v5i2.1750.

Maijarern, T., Chaiwut, N., \& Nobnop, R. (2018). Augmented reality for science instructional media in primary school. 3rd International Conference on Digital Arts, Media and Technology, ICDAMT. https://doi.org/10.1109/ICDAMT.2018.8376523.

Maison, M., Haryanto, H., Ernawati, M. D. W., Ningsih, Y., Jannah, N., Puspitasari, T. O., \& Putra, D. S. (2020). Comparison of student attitudes towards natural sciences. International Journal of Evaluation and 
Research in Education, 9(1), 54-61. https://doi.org/10.11591/ijere.v9i1.20394.

Marisda, D. H., \& Handayani, Y. (2020). Model Pembelajaran Kolaboratif Berbasis Tugas Sebagai Alternatif Pembelajaran Fisika Matematika. Fisika PPS UNM, 2(1), 9-12.

Muhammad, H. M. (2018). Keefektifan Model Pembelajaran Tebak Kata Terhadap Hasil Belajar Pada Tema 7 "Indahnya Keragaman Di Negeriku" Siswa Kelas Iv. Mimbar Ilmu, 23(3), 200-207. https://doi.org/10.23887/mi.v23i3.16436.

Narayani, W. (2019). Pengaruh Model Pembelajaran Nht Berbasis Tri Hita Karana Terhadap Karakter Dan Hasil Belajar IPA. Jurnal Pendidikan Multikultural Indonesia., 2(1). https: //doi.org/10.23887/jpmu.v2i1.20785.

Novika Auliyana, S., Akbar, S., \& Yuniastuti. (2018). Penerapan Pembelajaran Tematik Terpadu di Sekolah Dasar. Jurnal Pendidikan: Teori, Penelitian, Dan Pengembangan, 3(12), 1572-1582. https://doi.org/10.17977/jptpp.v3i12.11796.

Permana, E. P., \& Nourmavita, D. (2017). Pengembangan Multimedia Interaktif Pada Mata Pelajaran Ipa Materi Mendeskripsikan Daur Hidup Hewan Di Lingkungan Sekitar Siswa Kelas Iv Sekolah Dasar. Jurnal PGSD, 10(2), 79-85. https://doi.org/10.33369/pgsd.10.2.79-85.

Rahayuningsih, S. (2020). Animation media of animal husbandry thematic science learning to stimulate scientific attitude in early childhood. International Journal of Scientific and Technology Research. https://doi.org/10.23887/jet.v3i1.17959 Article Metrics.

Rosalina, S. S., \& Suhardi, A. (2020). Need Analysis of Interactive Multimedia Development With Contextual Approach on Pollution Material. INSECTA: Integrative Science Education and Teaching Activity Journal, 1(1), 93. https://doi.org/10.21154/insecta.v1i1.2107.

Rubini, B., Permanasari, A., \& Yuningsih, W. (2018). Learning Multimedia Based on Science Literacy on the Lightning Theme. Jurnal Penelitian Dan Pembelajaran IPA, 4(2), 89-104. https: //doi.org/10.30870/jppi.v4i2.3926.

Rusli, R., Rahman, A., \& Abdullah, H. (2020). Student perception data on online learning using heutagogy approach in the Faculty of Mathematics and Natural Sciences of Universitas Negeri Makassar, Indonesia. Data in Brief, 29, 105152. https://doi.org/10.1016/j.dib.2020.105152.

Sakliressy, M. T., Sunarno, W., \& Nurosyid, F. (2021). Students Scientific Attitude in Learning Physics Using Problem Based Learning Model with Experimental and Project Methods. Jurnal Ilmiah Pendidikan Fisika Al-Biruni. https://doi.org/10.24042/jipfalbiruni.v10i1.8347.

Santiasih, N. I., Marhaeni, A. A. I. N., \& Tika, I. N. (2013). Pengaruh Model Pembelajaran Inkuiri Terbimbing Terhadap Sikap Ilmiah dan Hasil Belajar IPA Siswa Kelas V SD No. 1 Kerobokan Kecamatan Kuta Utara Kabupaten Badung Tahun Pelajaran 2013/2014. Jurnal Pendidikan Dasar Ganesha, 3(1). https://doi.org/10.23887/jet.v3i1.17959 Article Metrics.

Saripudin, E., Sari, I. J., \& Mukhtar, M. (2018). Using Macro Flash Animation Media on Motion Material to Improve Learning Achievement for Learning Science in Junior High School. Jurnal Penelitian Dan Pembelajaran IPA, 4(1), 68-75. https://doi.org/10.30870/jppi.v4i1.3316.

Seruni, R., Munawaroh, S., Kurniadewi, F., \& Nurjayadi, M. (2020). Implementation of e-module flip PDF professional to improve students' critical thinking skills through problem based learning. Journal of Physics: Conference Series, 1521(4), 1-6. https://doi.org/10.1088/1742-6596/1521/4/042085.

Sintema, E. J. (2020). Effect of COVID-19 on the performance of grade 12 students: Implications for STEM education. Eurasia Journal of Mathematics, Science and Technology Education, 16(7), 1-6. https://doi.org/10.29333/EJMSTE/7893.

Subali, B., Kumaidi, Aminah, N. S., \& Sumintono, B. (2019). Student achievement based on the use of scientific method in the natural science subject in elementary school. Jurnal Pendidikan IPA Indonesia, 8(1), 39-51. https://doi.org/10.15294/jpii.v8i1.16010.

Suryani, N. K., Renda, N. T., \& Wibawa, I. M. C. (2019). Pengaruh Pendekatan Saintifik Berorientasi Tri Kaya Parisudha Terhadap Penguasaan Konsep Ipa Dan Keterampilan Proses Sains Siswa Kelas V Sd Di Gugus Vii Kecamatan Sukasada Kabupaten Buleleng Tahun Pelajaran 2018/2019. Journal of Education Technology. https://doi.org/10.23887/jet.v3i1.17962.

Suryawati, E., \& Osman, K. (2018). Contextual learning: Innovative approach towards the development of students' scientific attitude and natural science performance. Eurasia Journal of Mathematics, Science and Technology Education, 14(1), 61-76. https://doi.org/10.12973/ejmste/79329.

Syahputra, Y. S., Santosa, R., \& Supriyadi, S. (2017). Teacher'S Willingness Towards the Implementation of Scientific Approach: From Theory To Implementation. Journal of English Education, 2(2), 132-137. https://doi.org/10.31327/jee.v2i2.409.

Töman, U. (2017). Investigation to improve the process of pre-service teachers' reflective thinking skills through an action research. Universal Journal of Educational Research, 5(9), 1535-1548. https://doi.org/10.13189/ujer.2017.050911. 
Utomo, A. C., Abidin, Z., \& Rigiyanti, H. A. (2020). Keefektifan Pembelajaran Project Based Learning Terhadap Sikap Ilmiah Pada Mahasiswa PGSD. Educational Journal of Bhayangkara. https://doi.org/10.31599/edukarya.v1i1.103.

Widani, N. K. T., Sudana, D. N., \& Agustiana, I. G. A. T. (2019). Pengaruh Model Pembelajaran Inkuiri Terbimbing Terhadap Hasil Belajar IPA Dan Sikap Ilmiah Pada Siswa Kelas V SD Gugus I Kecamatan Nusa Penida. Journal of Education Technology, 3(1), 15-21. https://doi.org/10.23887/jet.v3i1.17959.

Widiartini, P. D. O., Made Putra, M. P., \& Manuaba, I. B. S. (2019). Pengaruh Model Pembelajaran Group Investigation Berbasis Tri Hita Karana Terhadap Kompetensi Pengetahuan IPA. Jurnal Ilmiah Sekolah Dasar. https: //doi.org/10.23887/jisd.v3i3.19476.

Yunanto, A. A., Herumurti, D., Rochimah, S., \& Kuswardayan, I. (2019). English Education Game using NonPlayer Character Based on Natural Language Processing. Procedia Computer Science, 1. https://doi.org/10.1016/j.procs.2019.11.158.

Zabolotniaia, M., Cheng, Z., Dorozhkin, E., \& Lyzhin, A. (2020). Use of the LMS Moodle for an Effective Implementation of an Innovative Policy in Higher Educational Institutions. International Journal of Emerging Technologies in Learning (IJET), 15(13), 172. https://doi.org/10.3991/ijet.v15i13.14945. 